Y

UCOMAT 2016 will be held September 5-10, in Herceg Novi, Montenegro. It is organized by the Materials Research Society of Serbia.

Six symposia will comprise invited plenary lectures, oral presentations, and poster presentations: Advanced Methods in Synthesis and Processing of Materials; Advanced Materials for High-Technology Applications; Nanostructured Materials; Eco-Materials and Eco-Technologies; Biomaterials; and Korea-EU-USA Satellite Symposium on Hybrid Materials and Processing Technology. The conference will also feature a tutorial for young researchers and an exhibition of synthesis and characterization equipment.

Awards will be presented to the authors (preferably members younger than 35) of the best oral and poster presentation at the conference, and also to the authors of highly rated $\mathrm{PhD}$ and MSc theses defended between two conferences.

The deadline for abstract submission is May 1. Preregistration ends June 15. A late fee will be processed for registrations submitted later than July 31. More information can be accessed from the conference website at www.mrs-serbia.org.rs/index. php/yucomat-2016m or by email at yucomat@mrs-serbia.org.rs.

\title{
MSE 2016 to be held September 27-29 in Germany
}

www.mse-congress.de

7 he Materials Science Engineering

1 Congress 2016 (MSE 2016) will be held September 27-29, in Darmstadt, Germany. The German Materials Society has organized the event, which offers an atmosphere for young researchers to connect with professionals and industries.
The following eight topics are structured into 61 symposia: Functional Materials and Devices, Structural Materials, Synthesis and Processing, Characterization, Modeling and Simulation, Biomaterials, Colloquium of Honor for Wolfgang Kaysser of Helmholtz-Zentrum Geesthacht, Germany, and USA-GERMAN
Networking Symposium on Materials Science and Engineering.

Registration opens February 15. Abstract submission opens February 15 and ends March 31. The program will be finalized in August. More information can be accessed from the conference website at www.mse-congress.de or by email at mse@mse-congress.de

NICE 2016 International Conference to be held October 16-19 in France www.nice2016-conference.com

$\mathrm{N}$ ature Inspires Chemistry Engineers (NICE) 2016, The 3rd International Conference on Bioinspired and Biobased Chemistry \& Materials, will be held October 16-19, in Nice, France.

Taking inspiration from nature, we can engineer new artificial materials and devices for many applications in a range of sectors, including industry, environment, medicine, military, and energy. To accomplish this, the fields of materials science, chemistry, physics, and biology work together to study the synthesis, directed self-assembly, and hierarchical organization of natural materials. The purpose of the conference is to bring together scientists, engineers, and managers from these different backgrounds in this emerging field.

The program will include plenary lectures, keynote lectures, short oral presentations, and posters. The three sessions are SmartTech, NanoTech, and BioTech.

The submission deadline is March 15. Notification occurs April 18. Early bird registration ends May 16. More information can be accessed from the conference website at www.nice2016conference.com or by email at contact@ nice-conference.com..

\section{New for 2016! \\ Your MRS Membership now includes online access to ALL MRS Publications.}

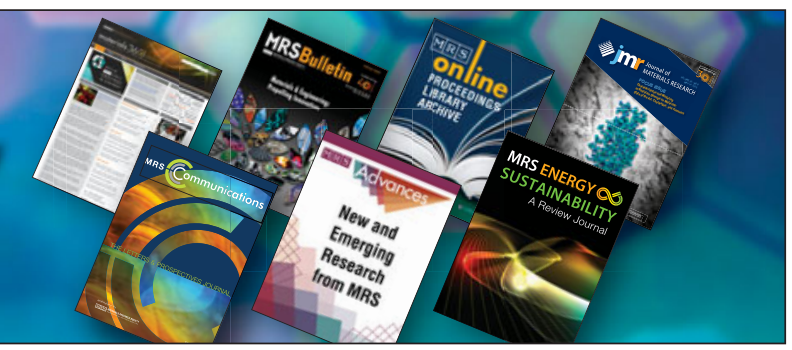

